\title{
Macrophages, microglial cells, and HLA-DR antigens in fetal and infant brain
}

\author{
M M Esiri, M S Al Izzi, M C Reading
}

\begin{abstract}
Immunohistochemical reactions for macrophages, microglia, and HLA-DR antigens were tested on frozen sections of necropsy brain tissue from 20 fetuses and infants ranging in age from 18 weeks' gestation to 8 months post term. No primary central nervous system disease was present but there were four cases of sudden infant death syndrome (SIDS). Macrophages were detected in all the samples studied and were located in the germinal matrix zone, in perivascular spaces throughout the brain, and in the leptomeninges and subependymal layer. Well differentiated microglia were present in all cases examined after 35 weeks' gestation and less well ramified forms were seen at earlier stages of gestation. HLA-DR antigens were detected on a small number of macrophages, chiefly in a perivascular location, in all but three cases. The fewest reactive cells and the weakest reactions occurred in the youngest fetuses. One case of SIDS showed increased foci of microglia in perivascular white matter: this case and one other case of SIDS were the only cases with well ramified microglia that expressed HLA-DR antigens.

These findings may be relevant to an understanding of local immune responses in fetal brain infections, including human immunodeficiency virus infection.
\end{abstract}

Cells of the mononuclear phagocyte system have been found in many organs of the human fetus beginning with the yolk sac at four weeks' gestation. ${ }^{1}$ Since the early work of Hortega, ${ }^{23}$ many studies have been carried out on the timing and appearance of macrophages and microglial cells in the developing nervous system of animals. Most, ${ }^{4-12}$ but not all, ${ }^{13-16}$ recent authors accept the view that resting as well as reactive microglia are derived from circulating blood monocytes, and that they belong to the mononuclear phagocyte lineage of cells. Macrophages enter the developing nervous system around the time of birth in mice $^{7}$ and rats, ${ }^{517}$ and before birth in rabbits. ${ }^{1218}$ In mice cells identified by the monoclonal antibody $\mathrm{F} 4 / 80$, which reacts with a macrophage-specific antigen, and by antibodies to receptors for the FC portion of immunoglobulins and the type 3 receptors for complement, were followed through a series of transitional forms from macrophages to resting microglia as development proceeded. ${ }^{7}$

Immunohistological studies of developing microglia in the immature human brain have rarely been described. An obstacle to the performance of such studies has been the lack, until recently, of suitable markers for human tissue macrophages in sections. This has now changed, however, with the production and characterisation of monoclonal antibodies that show high specificity for human tissue macrophages. These are listed in the proceedings of the 5th International Workshop on leucocyte antigens. ${ }^{19}$ Some of them have been shown to react with normal and reactive microglia as well as with perivascular, ependymal, and subarachnoidal macrophages in adult human brain. ${ }^{9020-22}$ Using such antibodies we now report the presence of macrophages and microglia in human fetal and infant brain. We also show that some, but not all, of the macrophages in immature human infant brain express HLA-DR antigens.

\section{Methods}

Brain samples were examined from 20 necropsy fetuses and infants ranging from gestational week 18 to a postnatal age of 8 months (table). The fetuses were delivered as the result of spontaneous onset of premature labour. Neither they nor those delivered at term showed evidence of clear cut brain pathology. The four infants dying beyond the perinatal period were cases of sudden infant death syndrome (SIDS) in which no clinically important pathology was shown at necropsy.

Blocks of tissue were taken from the periventricular region at the level of the head of the caudate nucleus and from the medulla. Samples of cerebral cortex and overlying leptomeninges were included in the blocks taken from the younger fetuses. Tissue blocks were snap frozen in liquid nitrogen and stored at $-70^{\circ} \mathrm{C}$ until cryostat sections were cut. Immunocytochemistry was carried out using monoclonal antibodies EBM11, Y1/82A, and L243. Specificity of these antibodies for macrophages (EBM $11^{20}$ and $\mathrm{Y} 1 / 82 \mathrm{~A}^{23}$ ) and HLA-DR antigens (L243) ${ }^{24}$ have already been described. ${ }^{19}$ Endogenous peroxidase was blocked by pretreatment of sections with $0.03 \% \mathrm{H} 202$ in TRIS-saline for 30 minutes before application of the primary antibody. Antibodies EBM11 and Y1/82A were applied neat and L243 at 1 in 100 dilution in TRISsaline $(\mathrm{pH} \mathrm{7.6)}$ to serial cryostat sections (fixed in acetone for 10 minutes at room 
Chronological list of cases studied with semiquantitative macrophage, microglial, and $H L A-D R$ scores

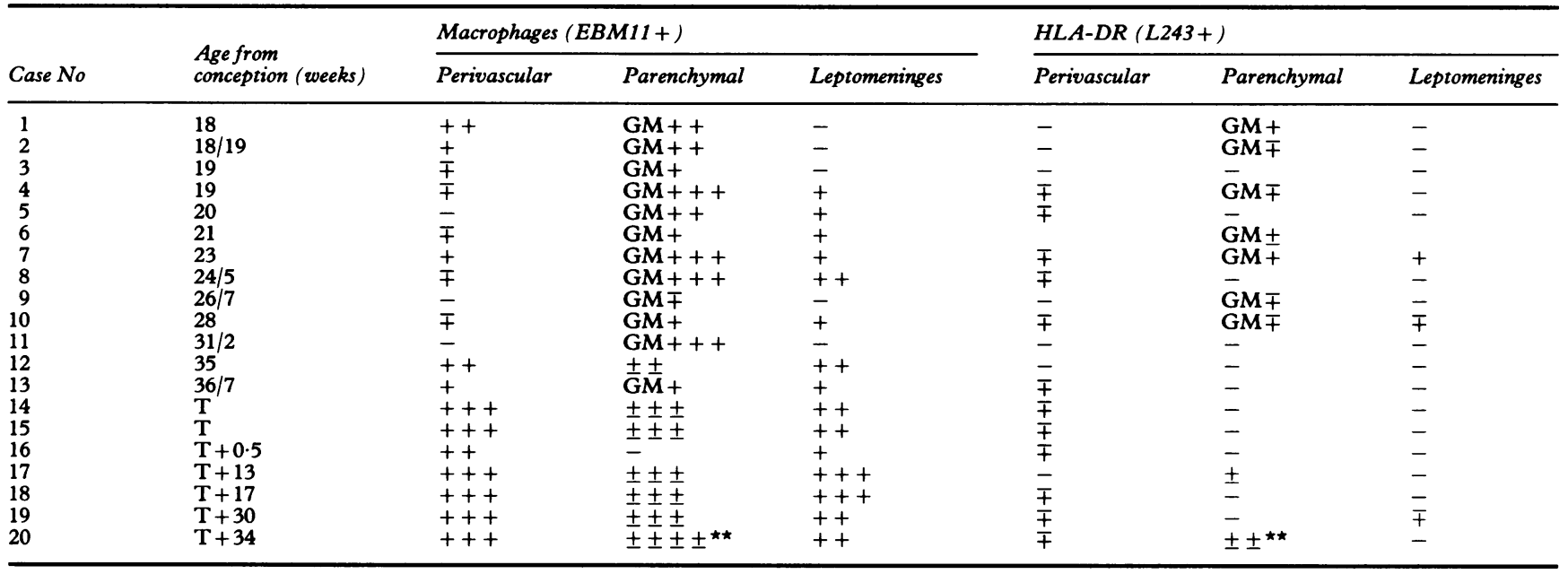

$\star^{\star} \mathrm{GM}=$ Germinal matrix macrophages; scores underlined are well differentiated microglia.

$\star \star$ Includes focally increased number of microglia.

Scores: - : absent; $\mp$ : rare; $+:$ few; ++ : moderate numbers; $+++:$ many reactive cells.

temperature) for 45 minutes. Sections were then thoroughly washed in TRIS-saline, treated with peroxidase-conjugated antimouse immunoglobulin (P260) (Dako) or Vectastain ABC peroxidase (Vector) and the reaction product developed in diaminobenzidine for five minutes at room temperature. Sections were counterstained with haematoxylin and mounted in DPX. Control sections were treated in the same way but had primary antibodies omitted or replaced by an irrelevant mouse monoclonal antibody.

\section{Results}

The results are summarised in the table. Some cells reacting with the macrophage antibodies were present in the brain sections from all cases. Reactive cells were mainly of two types: large cells with abundant cytoplasm surrounding the nucleus, sometimes extending into short processes. These cells resembled macrophages (fig 1). Smaller cells with fine, branch-

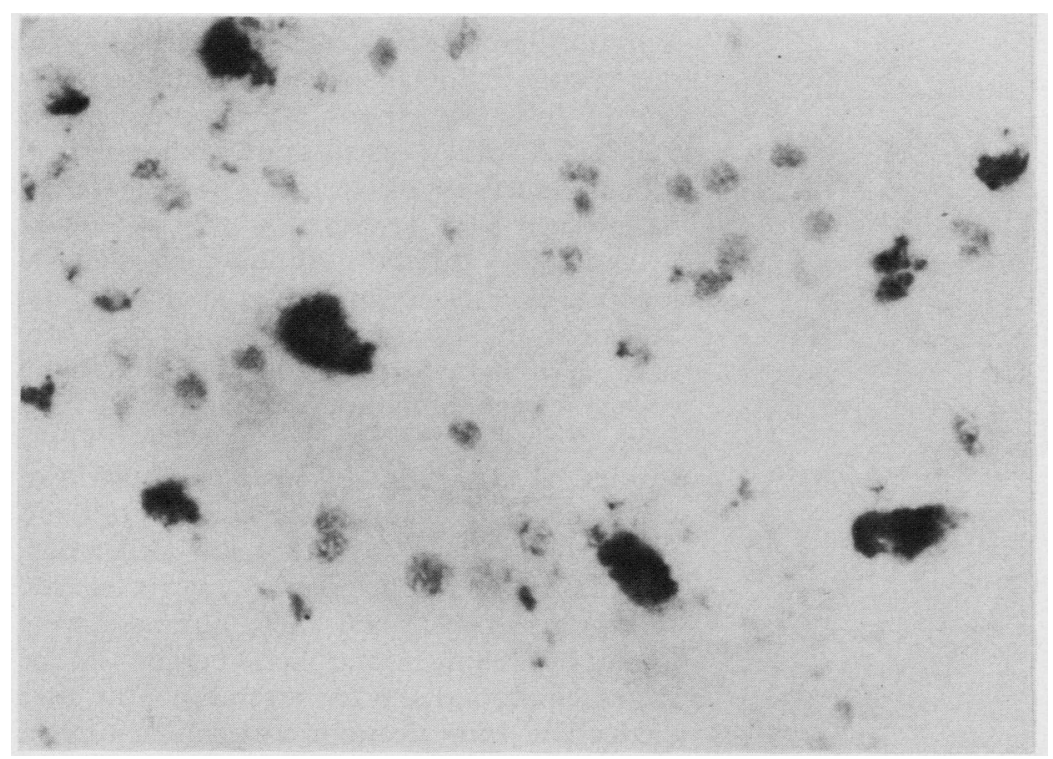

Figure 1 Case 10, 28 week fetus. Round-bodied macrophages in periventricular white matter reactive with monoclonal antibody $Y 1 / 82 \mathrm{~A}$ (weak haematoxylin counterstain.) ing processes were also seen and resembled microglia (fig 2). Macrophages were found regularly in a perivascular location throughout grey and white matter, in the germinal matrix overlying the head of the caudate nucleus and in the leptomeninges (figs 3-5). They were also occasionally found in the subependymal region in the walls of the lateral and fourth ventricles. Fully developed microglia were found in grey and white matter from 35 weeks' gestation. These cells reacted better with EBM11 than Y1/82A antibody. In the preterm fetuses they were not as numerous as in term and post-term infants or mature adult brain, and they had fewer and shorter ramifying processes preterm. Some intermediate forms between macrophages and microglia were seen chiefly just beyond the germinal matrix, particularly in fetuses of less than 35 weeks' gestation. In the most mature brain studied, from a case of SIDS, there were foci of increased numbers of reactive microglia in white matter. In the germinal matrix macrophages were fairly evenly dispersed among the densely packed immature neural elements, but their density varied considerably from case to case. This density was not clearly related to gestational age-for example, the greatest densities of macrophages in this zone were found at quite widely differing stages of fetal life -19 and 32 weeks' gestation. It was clear, however, that in the younger fetuses (less than 28 weeks' gestation) the germinal matrix contained the greatest concentration of reactive cells when compared with the rest of the brain, perivascular macrophages elsewhere being rare at this age. It was impossible to be certain whether germinal matrix macrophages were situated around vessels, because the vessels themselves were sometimes hard to discern. Some macrophages in this zone seemed to be located near foci of apoptosis or nuclear karryorhexis. Leptomeningeal macrophages were very sparse in the youngest fetuses but common in the older ones and in post-term infants.

HLA-DR antigens were clearly detectable on a few macrophages in all except three fetuses 


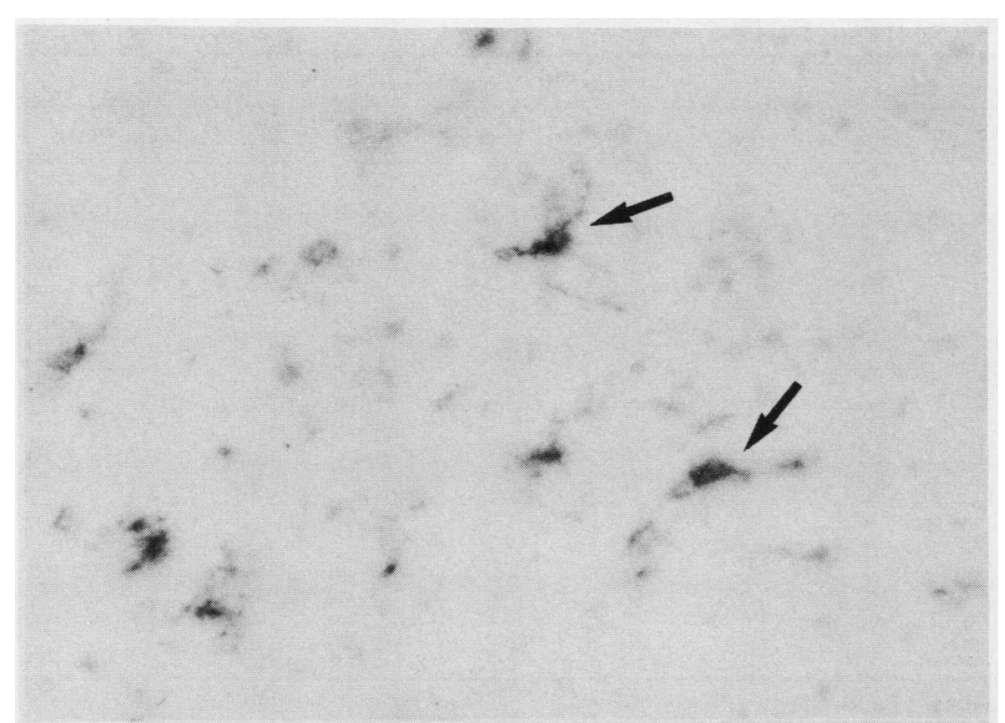

Figure 2 Case 19, term delivery with sudden infant death at 30 days. Process-bearing microglia (arrows) reactive with monoclonal antibody EBM11 in cerebral white matter (weak haematoxylin counterstain.)

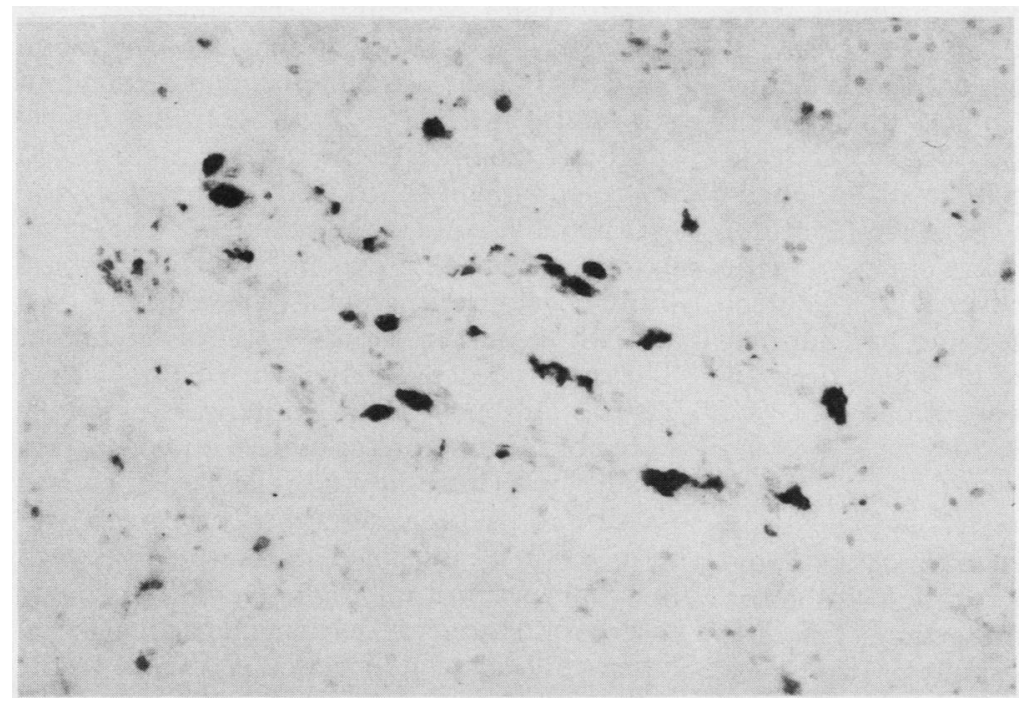

Figure 3 Case 20, term delivery with sudden infant death at 34 days. Perivascular macrophages in cerebrum reactive with monoclonal antibody $Y 1 / 82 \mathrm{~A}$ (weak haematoxylin counterstain.)

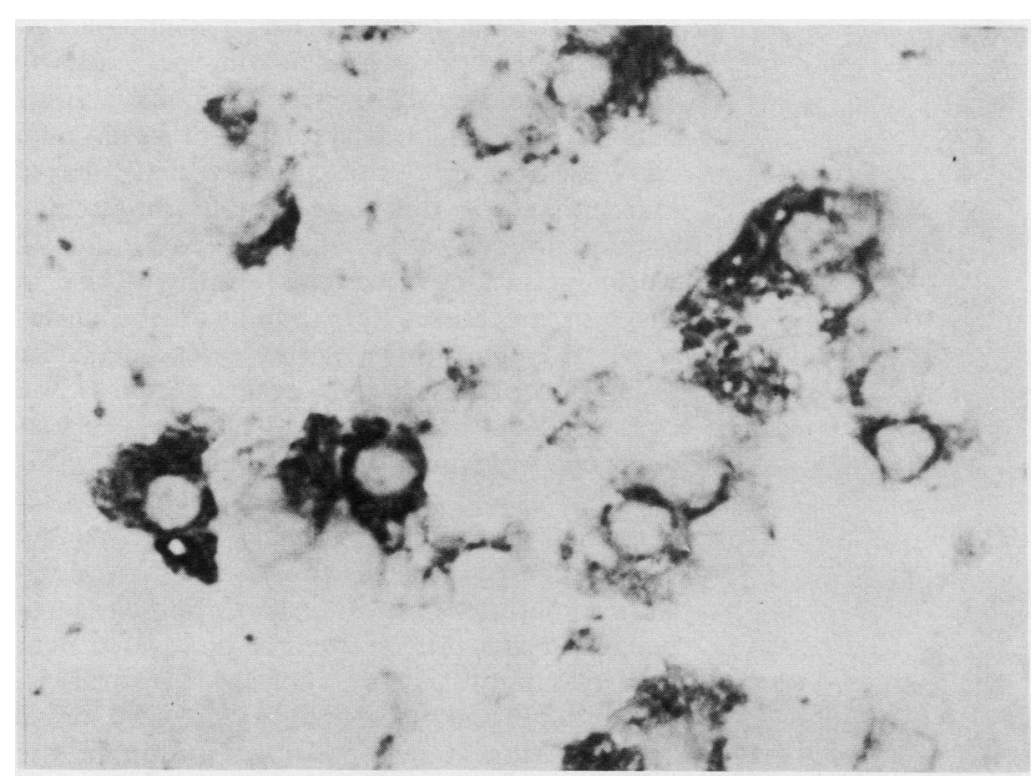

Figure 4 Case 11, 31/2 week fetus. Germinal matrix zone showing several macrophages reactive with monoclonal antibody EBM11 (weak haematoxylin counterstain.) (table). They were most frequently detected on perivascular macrophages (fig 6), but were also present on occasional macrophages in the germinal matrix (fig 7) or leptomeninges. HLADR positive macrophages in the germinal matrix may have been perivascular; occasionally a cluster of two to three was found. In the younger fetuses the reaction was weakest. Microglia were not reactive for HLA-DR except in the foci of reactive microglia from the most mature case of SIDS studied, and in one other case of SIDS in which HLA-DR was seen in a patchy distribution on microglia in grey and white matter (fig 8).

\section{Discussion}

It has been suggested from studies in animals that the stimulus for the initial entry of monocytes into the developing nervous system and their differentiation to form macrophages and microglia may be the programmed death of neurons. Thus macrophages make their appearance in developing mouse retina during the phases of cell death in the ganglion cell and inner nuclear layers and can be seen closely apposed to degenerating neurons in these layers. ${ }^{6}$ Similar observations were made on the mouse brain by Perry et al. ${ }^{7}$ In rodents these events occur shortly before and at the time of birth. In the developing rabbit retina, however, microglia precursors enter the retina before programmed cell death occurs in retinal ganglion and amacrine cell populations. ${ }^{12}$

Little is known about the timing of these events in nervous system development in man. ${ }^{25}$ In this study, however, macrophages were found to have entered the nervous system by mid-fetal life, and well differentiated microglia were present from 35 weeks' gestation.

In mouse embryos macrophages were predominantly localised initially to "hot spots" from which they later spread out to become more or less evenly distributed throughout the brain." One of these "hot spots" is in the periventricular white matter close to the corpus callosum. This localisation may be comparable with the high density of macrophages found in the youngest human fetuses in the germinal matrix overlying the head of the caudate nucleus. A similar distribution of microglia in human fetuses of 24 weeks' or more gestation has recently been described. ${ }^{26}$

Although specific immunohistochemical identification of macrophages in developing human brain has rarely been described, ${ }^{26}$ there have been many studies of lipid-containing cells in human immature brain, following their first description by Virchow in $1867 .{ }^{27}$ These studies have highlighted an accumulation of such cells in periventricular white matter and the corpus callosum. Mickel and Gilles described such cells in the germinal matrix from 30 weeks' gestation, ${ }^{28}$ and their numbers were found by Jellinger and Seifelberger ${ }^{29}$ to be increased around and for several months after birth. The clinical importance and nature of these cells has been uncertain. Although pathological changes are known to occur in this 


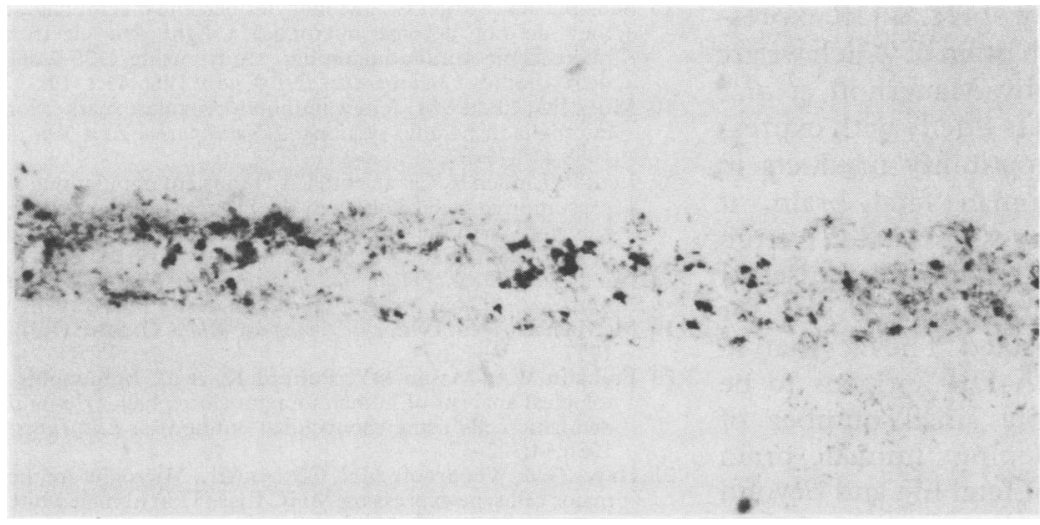

Figure 5 Case 8, 24/5 week fetus. Portion of leptomeninges containing many macrophages reactive with monoclonal antibody EBM11 (weak haematoxylin counterstain.

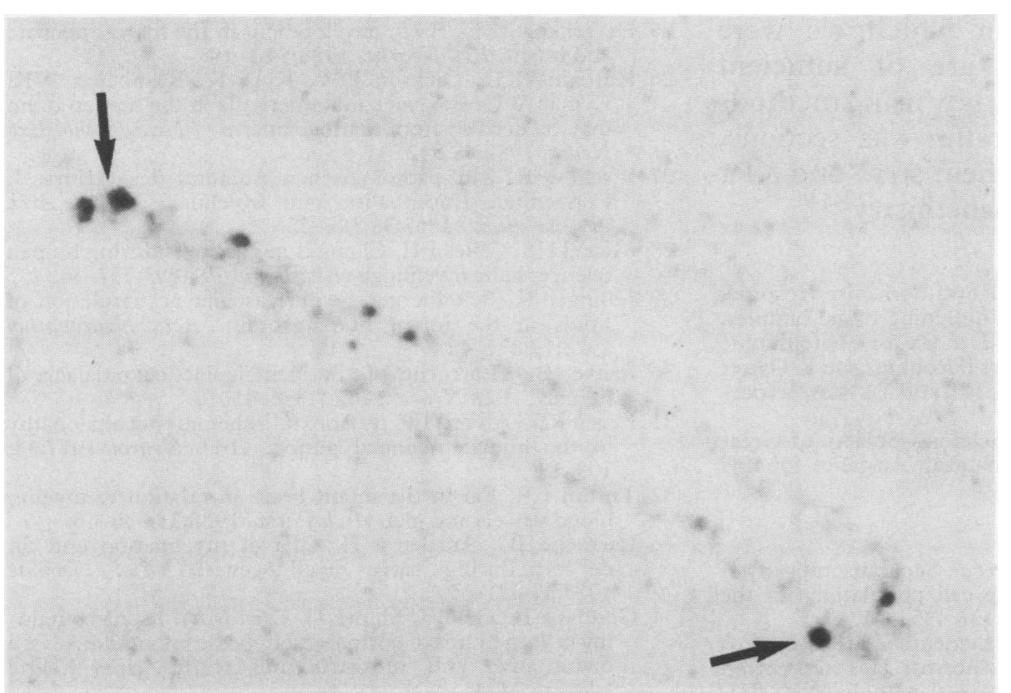

Figure 6 Case 19, term delivery with sudden infant death at 30 days. Perivascular macrophages in cerebral white matter reactive with anti-HLA-DR monoclonal antibody L243 (arrows) (weak haematoxylin counterstain.)

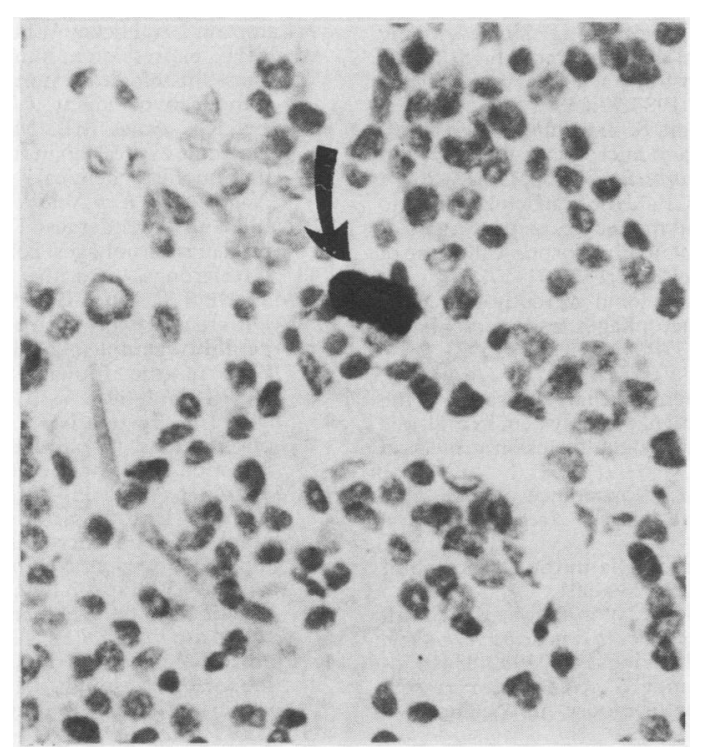

region in some immature brains, ${ }^{30}{ }^{31}$ it has been suggested that these cells may be a feature of normal development. ${ }^{32} 33$ This view is supported by a recent study of lipid-containing cells in infant monkeys in which the numbers of such cells were related to age and state of myelination of the corpus callosum, and not to whether the monkeys had been subjected to an episode of severe hypoxia before death. ${ }^{34}$ The ultrastructural appearances of these lipid-containing cells in infant monkeys were compatible with them being reactive microglia, but they were not considered distinctive enough to confirm their microglial nature. The present finding of macrophages and cells intermediate in form between macrophages and microglia in fetal and infant periventricular white matter and germinal matrix add to the likelihood that at least some of the lipid-containing cells described in human and other primate infant brains are of mononuclear phagocyte origin. It is of interest that lipid-containing cells are modestly increased in periventricular corpus callosum white matter in SIDS SI $^{36}$ and that in the present study one of the four cases of SIDS studied showed increased numbers of immunocytochemically identified microglia in periventricular white matter.

The presence of HLA-DR antigens on some of the macrophages found in developing human brain in this study is of interest. Perivascular macrophages, which were those most frequently found to express HLA-DR, also express these antigens in adult brain, in contrast to normal resting microglia which have usually been found to be only barely reactive or unreactive..$^{23}$ 37-40 Increased expression of HLA-DR on reactive microglia in relatively normal white matter in multiple sclerosis ${ }^{21}$ is well described in adult brain, and it is of interest that in two cases of SIDS microglia clearly expressed HLA-DR antigens. Expression of HLA-DR antigens by macrophages is known to be increased by gamma interferon. ${ }^{41}$ 
The only published study of HLA-DR expression in developing human brain of which we are aware is that reported by Mauerhoff et al. ${ }^{42}$ Although their study dealt chiefly with expression of major histocompatibility products in cells cultured from human fetal brain, it included a study of cryostat sections from unspecified sites from three human fetuses of unspecified age in which no cells positive for class II product were detected. The fact that, in contrast, we found HLA-DR antigens to be regularly expressed on a small number of macrophages in developing human brain during the second half of fetal life and beyond may be relevant to an understanding of local immune responses in fetal brain infections, including human immunodeficiency virus infection which may affect offspring of mothers infected with this virus. ${ }^{43}$

This study was, to some extent, limited in its size and scope by the need to examine frozen sections in order to preserve the macrophage and HLA-DR antigens in which we were interested. The findings are of sufficient interest to warrant further study using methods that can be applied to paraffin wax sections, such as RCA-1 lectin histochemistry ${ }^{44}$ and KP1 and HAM 50 immunohistochemistry. ${ }^{45} 46$

We thank the pathology staff of the Royal Berkshire Hospital, Reading, Berks, for the assistance in obtaining tissue samples, and Mr G Richardson and Miss Pat Deacon for photographic
work. Professor J O'D McGee and Drs P Robbins and K Gatter kindly supplied antibodies EBM11, L243, and Y1/82A, respectively.

We are grateful to the Multiple Sclerosis Society of Great We are grateful to the Multiple Sclerosis Society of Great
Britain and Northern Ireland for financial assistance for this study.

1 Janossy G, Bofill M, Poulter LW, et al. Separate ontogeny of two macrophage-like accessory cell populations in the human foetus. J Immunol 1986;136:4354-61.

2 Hortega P del Rio. El "Tracer elemento" de los centros nervios. I. La microglia enestado normal. II. Intervención de la microglia en los processos pathologicos. III Naturaleza probable de la microglia. Biol Soc Exp Biol Naturaleza pro

3 Hortega P del Rio. Microglia. In: Penfield W, ed. Cytology and cellular pathology of the nervous system. New York: Hoeber, 1932:482-534

4 Baldwin F. Microglia and brain microphages In: Carr I, Daems WT, eds. The reticulo endothelial system. A compre hensive treatise Vol 1. New York: Plenum Press, 1981: 635-69.

5 Murabe Y, Sano Y. Morphological studies on neuroglia VI Postnatal development of microglial cells. Cell Tissue Res 1982;225:469-85.

6 Hume DA, Perry VH, Gordon S. Immunohistochemical localisation of a macrophage specific antigen in developing mouse retina: phagocytosis of dying neurons and differenmouse retina: phagocytosis of dying neurons and differentiation of microglial cells to form a regular
plexiform layers. J Cell Biol 1983;97:253-7.

7 Perry VH, Hume DA, Gordon S. Immunohistochemical localisation of macrophages and microglia in the adult and developing mouse brain. Neuroscience 1985;15:313-26.

8 Ling EA, Penney D, Leblond CP. Use of carbon labelling to demonstrate the role of blood monocytes as precursors of the "amoeboid cells' present in the corpus callosum of postnatal rats. J Comp Neurol 1980;193:631-57.

9 Esiri MM, McGee JO'D. Monoclonal antibody to macrophages (EBM11) labels macrophages and microglia in normal human brain. J Clin Pathol 1986;39:615-21.

10 Woodroofe MN, Bellamy AS, Feldmann M, Davison AN, Cuzner ML. Immunocytochemical characterisation of the immune reaction in the central nervous system in multiple sclerosis. Possible role for microglia in lesion growth. $J$ Neurol Sci 1986;74:135-52.

11 Boya J, Calvo J, Carbonell AL. Appearance of microglial cells in the post natal rat retina. Arch Histol Jpn 1987;50:223-8.

12 Ashwell $\mathrm{K}$. Development of microglia in the albino rabbit retina. J Comp Neurol 1989;287:286-301.

13 Oemichen M. Functional properties of microglia. In: Smith WT, Cavanagh JB, eds. Recent advances in neuropathology. Vol 2. Edinburgh: Churchill Livingstone, 1982:83-107.

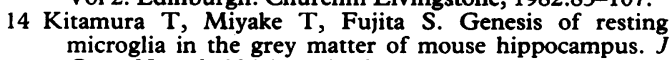
Comp Neurol 1984;226:421-33.
15 Schelper RI, Adrian EK. Monocytes become macrophages; they do not become microglia: a light and electron microscopic autoradiographic study using 125-I.domicroscopic autoradiographic study using 125-1.do-

16 Miles JM, Chou SM. A new immunoperoxidase marker for microglia in paraffin sections. $J$ Neuropathol Exp Neurol 1988;47:579-87.

17 Lent R, Linden R, Cavalcante LA. Transient populations of presumptive macrophages in the brain of the developing hamster, as indicated by endocytosis of blood-born horseradish peroxidase. Neuroscience 1985;15:1203-15.

18 Lund RD. Development and plasticity of the brain. An introduction. New York: Oxford University Press, 1978.

19 McMichael A, ed. Leucocyte typing workshop. Oxford: OUP, 1957

20 Franklin WA, Mason DY, Pulford K, et al. Immunohistological analysis of human mononuclear phagocytes and dendritic cells using monoclonal antibodies. Lab Invest 1986;54:322-35.

21 Hayes GM, Woodroofe MN, Cuzner ML. Microglia are the major cell type expressing MHC Class II in human white matter. J Neurol Sci 1987;80:25-37.

22 Esiri MM, Reading MC. Macrophage populations associated with multiple sclerosis plaques. Neuropathol Appl Neurobiol 1987;13:451-65.

23 Davey FR, Cordell JL, Erber WN, et al. A monoclonal antibody (Y1/82A) with specificity towards peripheral blood monocytes and tissue macrophages. J Clin Pathol 1988;41:753-8.

24 Robbins PA, Evans EL, Ding AH,. Warner NL, Brodsky FM. Monoclonal antibodies that distinguish between Class II antigens (HLA-DP, DQ and DR) in 14 haplotypes. Hum Immunol 1987;18:301-13.

25 Herschkowitz N. Brain development in the foetus, neonate and infant. Biol Neonate 1988;54:1-19.

26 Hutchins KD, Dickson DW, Kure K, Rashbaum WK, Lyman WD. Evidence that microglia in the human brain may be derived from neuroectoderm. $J$ Neuropathol Exp Neurol 1989;48:342.

27 Virchow R. Zur pathologischen Anatomi des Gehirs. I. Congenitale Encephalitis und Myelin. Virchows Arch (Pathol Anat) 1867;38:129-38.

28 Mickel HS, Gilles FH. Changes in glial cells during human telencephalic myelinogenesis. Brain 1980;93:337-46.

29 Jellinger K, Seitelberger F. Perivascular accumulation of lipids in the infant human brain. Acta Neuropathol $1971 ; 19: 331-42$.

30 Banker BQ, Larroche JC. Periventricular leukomalacia of infancy. Arch Neurol 1962;7:386-410.

31 Leech RW, Alvord EC Jr. Anoxic-ischemic encephalopathy in the human neonatal period. Arch Neurol 1977;34: 109-13

32 Tuthill CR. Fat in the infant brain in relation to myelin blood vessels and glia. Arch Pathol 1938;25:336-46.

33 Larroche JC, Amakawa $H$. Glia of myelination and fat deposit during early myelinogenesis. Biol Neonate 1973;22:421-35.

34 Goddard-Finegold J, Sloper JJ, Esiri MM. Lipid-containing cells in brains of normal and hypoxic infant monkeys: a quantitative and ultrastructural study. Ann Neurol 1989;26:34-41.

35 Gadson DR, Emery JL. Fatty change in the brain in perinatal and unexpected death. Arch Dis Child 1976;51:42-9.

36 Esiri MM, Kahn P, Keeling J. Lipid-containing cells in the brain in sudden infant death syndrome. Devel Med Child Neurol 1990;32:319-24.

37 Daar AS, Fuggle SV, Fabre JW, Ting A, Morris PJ. The detailed distribution of MHC Class II analysis in normal human organs. Transplantation 1984;38:293-8.

38 Hauser SL, Bhan AK, Gilles FH, et al. Immunohistochemical staining of human brain with monoclonal antibodies that identify lymphocytes, monocytes and the Ia antigen. $J$ Neuroimmunol 1988;5:197-205.

39 Lampson LA, Hickey WF. Monoclonal antibody analysis of MHC expression in human brain biopsies: tissue ranging from "histologically normal" to that showing levels of glial from "histologically normal" to that showing levels of

40 Sobel RA, Ames MB. Major histocompatibility complex molecule expression in the human central nervous system: immunohistochemical analysis of 40 patients. Neuropathol Exp Neurol 1988;47:19-28.

41 Nathan CF, Prendergast TJ, Weibe ME, et al. Activation of human macrophages: comparison of other cytokines with interferon $\%$ J Exp Med 1984;160:600-5.

42 Mauerhoff T, Pujol-Borrell R, Mirakiam R, Bottazzo GF. Differential expression and regulation of major histocompatibility complex (MHC) products in neural and glial cells of the human foetal brain $J$ Neuroimmunol 1988;18:271-89.

43 Sharer LR, Epstein LG, Cho ES, et al. Neuropathological observations in children with AIDS and HTLV-III infection of the brain. Hum Pathol 1986;17:271-84.

44 Mannoji $H$, Veger $H$, Becker LE A specific histochemical marker (Lectin Ricinus communis agglutinin-1) for marker (Lectin Ricinus communis agglutinin-1) for topathology. Acta Neuropathol 1986;71:341-3.

45 Adams CMW, Poston RN, Buk SJ. Pathology, histochemistry and immunocytochemistry of lesions in acute multiple sclerosis. J Neurol $S c i$ 1989;92:291-306.

46 Pulford KAF, Rigney EM, Micklem KJ, et al. KP1: a new monoclonal antibody that detects a monocyte/macrophage associated antigen in routinely processed tissue sections. $J$ Clin Pathol 1989;42:414-21. 